\title{
Fat Man at the Margin: The Poetry of Richard Hugo
}

\section{Frederick Garber}

Richard Hugo's poems are infused with an essential strangeness that is both immediate and pervasive, the first and last qualities in all the landscapes where things happen to him. It is comforting to say that Hugo is a regional poet, a celebrator of place who stares out at the Pacific Northwest; but its glance meets his stare as a lighthouse beacon hits the eye of a beguiled fish. Furthermore, the region in which he is located is as much within him as without, and most often in both places at once. The landscape where things happen to Hugo goes as far into his mind as it goes outside of it, and the landscape inside has a relationship with the one outside which words like contiguity and continuity, separately or together, cannot exhaust. In part the poetry-like that of Stevens or William Stafford-is about the meeting of these landscapes. Thus, if we want to call Hugo a regional poet we have to extend the region he encompasses to include the mind which makes the poems out of those meetings. $\mathrm{He}$ and his mind move out from the beaches of the Olympic Peninsula to the house of a just-dead drunk, deep into Italy and out to Montana ranches, into places that are no longer here and others that ought never to have been anywhere. Wherever it goes, this mind is never entirely surprised. Perhaps that means that the strangeness too is as much within him as without, that the confrontations of landscapes are really shocks of recognition. There is, after all, that within himself which can seem as dark as the darkest waters. But Hugo is never that easy a poet. An immense compassion links him to all other men without making him one of them, while his awareness of men as natural objects is wildly overweighed by his sense of them as men. Shocks of recognition are surely there, but his inner landscape is still the mind of a man and not a fish, its strangeness a human strangeness, and his ability to recognize likeness is the property of an isolated but percipient intelligence which watches those like itself at war with each other and with their surroundings.

This intelligence can entice more out of some surroundings than it can out of others, which is not to say that Hugo is limited (the Italian poems show that he is not) but that what he sees is usually seen most clearly in certain conditions. On the whole his is not a citified intelligence: in the city, he has said, it is difficult 
simply to see any one person or thing for very long, while in the country his sensibility is not flooded or forced to delete in order to understand. To this we ought to add another comment of his, that poets (Hugoesque poets) are conservative about life because they want things to stay long enough for the poets to understand them with full sensibility. And one more remark, published in the New American Review, should help toward fathoming the center of Hugo's sense of the world: poets need few things, he said, and among those are "a brief look at something most people ignore." Hugo's imagination hugs immutable starkness and seeks out, with awe, the locale of bare confrontations. The essential Hugoesque landscape is a beach, and the fundamental activity in it is the stare of a man at the alien sea. Run of Jacks is therefore not only his first book but his most basic one, for what occurs there is so radical that everything after it, better or worse, has not changed the lineaments of that act:

Your land ends at this border, water and stone, mobile in tide, diffuse in storm, but here.

The final fist of island rock

does not strike space away. Swim

and you are not in your country.

("La Push")

The rhythms in these poems are taut, muscular, nervous, probing what his world sounds like and what it dances to. These lines hold no empty spaces for sounds to echo in, because the landscape (within and without) has no blanks where anything can rest. The immense pressure within Hugo's language, then, renders exactly the intense density of what he sees. He stands in a town at the edge of the sea, facing out from the Olympic Peninsula to the Pacific which begins where all that is like him ends. Here at the margin he can see most clearly the packedness of every fragment of experience, even up to the rim where another kind of country starts. When the density he sees is not only theme but becomes part of the way the poem reaches us-in the rapid jumps from one image to another, in the compacted pressure of the words which are driven into relations by the rhythms-then this kind of Hugoesque poem achieves its complete effeot, taking the reader into La Push and all its related landscapes at every possible level of experience. Hugo's compulsion to see density is so instinctive and ineradicable that he seeks for a landscape like this as a place in which to ease the urgency of the instinct. When he and the landscape are in so open a relationship that his imagination meets no barriers, the compulsion can lead him even into the country of elemental foreignness, where he sees the busy density in every scrap of its experience:

Here at last is ending.

Where gray coordinates with nothing

the horizon wrinkles in the wind.

These will end: shrimp a mile

below, blue shark, sole,

rocks alive as crabs in shifting green, 
patent bathers, barnacles, kelp that lies

in wilting whips, jelly-

fish that open lonely as a hand,

space that drives into expanse, boredom banging in your face, the horizon stiff with strain.

\section{(“Ocean on Monday")}

Curiously, the overwhelming amplification which is the city's essential act can (though it doesn't always) blot out Hugo's awareness of the pressure every fragment holds. But even there, especially around the edges, Hugo can exercise the primary forms of his imagination and dance at the recognition of the unremittingly alien: "First South and Cambridge" does this brilliantly. And some poems place men of the city just at the boundary where a brute struggle ensues, one which they often lose. The men, their houses and wives, in "West Marginal Way" live out all the meanings of the pun to which their street name leads their lives; while "A District in the City" puts them at a point where that which is enticingly not of their kind begins to emerge. Still, even in landscapes which are far from these marginal ways this humanized (though not humanizing) imagination cannot put a world together without a man inside of the landscape looking at it. The act of confrontation, after all, goes deep within a mind as well as far outside of it. Sometimes a version of the ubiquitous fat man looks out at the sea, as in "Cape Alava" where, "at this west-most U.S. point," a clown sails a stone into the wind:

I build a shack and wait for candy odors

in the wind, a current from Rangoon.

Ships go by on radar, but a withered clown

can fix position on a rock in air.

But if this is the radical image of confrontation it is not the exclusive one, and the beach is only, finally, a visible kind of boundary. The history of the Northwest has studded the landscape with the leavings of many men who stood up to the edge of things, with the cities behind them and the elementally foreign just at the end of their fingertips. There, trying to turn the foreign into themselves, they grubbed a bleak sustenance which might have built the bones of a city but might equally have gone nowhere at all (as in the great "Montana Ranch Abandoned" in a later collection). Men at the edge are finding a place to be, perhaps with the knowing pain of the clown at Cape Alava, often with characters at a more blunted stage of awareness whose sensibilities are as bleak as the lands they hold on to.

Hugo finds these characters here and now, though he does not always find them alive or in anything like a pristine state. In fact, their ability to be found at all depends upon their insignificance: one remembers that this most conservative modern wants "a brief look at something most people ignore." What endures of man may well have survived because men neglect it. Sometimes the shreds alone are sufficient, for here a man has been, and if the men who were there 
knew less than the poet and his doubles know, what is left of those men-stubborn fragments that may be no more than the stumps of a burned-out booze hall-is left partly because they were too uninteresting for most curious stares. In a whole series of poems Hugo stands where they did or where their vestiges are now, himself again at a margin, this time that between past and present, between the memories of others which his imagination lifts into presentness, and the irrevocable immediacy of that presentness. Margins are places where things change into other things, and Hugo's stereoscopic vision (one of his most brilliant repeated feats of the imagination) sees the past and the present and the point of change all together and at once. This is an elegiac conservatism which pores over the past of the enduringly minimal, finding significance in the remains of what is no longer quite viable. The past opens up at the point where he stands, and if Hugo's sensibility is immediate (he claims not to be good at working out of memory) his compassion leaps into the dead worlds of others and rebuilds marginal existences out of monuments. Old voices haunt the cleaner church in "A Chapel Further West than Most:"

She was way off key that girl of farms

old from hoeing stone

and farming soil the worms and crows ignore

she sang loud enough to be alone

hitting notes that only dogfish hear.

But some graves at Mukilteo will do:

It's so out of way. Here

the sheriff might find a stolen car

abandoned. A boy will get his first

in the tall grass back of Laroway

and Wong where maples screen

the moonlight from the house next door

while markers spall and the mayor regrets

the dead can be this derelict.

Their disease was motto and the gold beyondours what fifty years have done to dying.

Today we come for nothing

but we read the sea and wait.

\section{("Graves at Mukilteo")}

In "Schoolgirl at Seola" the stereoscopy is precise:

To her a store has never been lethargic or built without dural.

Why should she believe the road she came on was not always road, the swimmer's sand once hard in wind and steep, or where those proud homes post high value in a lawn or child who never swears, an adult idiot played with stiffening eels? 
If these begin as poems about the immediate scene, the meaning of the immediate is fully possessed only by including that which preceded it and the map of the consciousness which is perceiving it all:

Arriving here is feeling some old love-

half a memory-a silly dream of how

a war would end, a world would settle down

with time for hair to gray before you die.

The other half of memory is sight.

The cliffs will hold another thousand years.

The town is rotting every Sunday night.

("Port Townsend")

This last poem is from Hugo's second book, Death of the Kapowsin Tavern. The move from Run of Jacks to that book changes no basic structures at the center of Hugo's experience but there is a shift toward a relative fullness within the immediate present. The past cannot be wiped out: it broods over all of Hugo's moves. But now he is drawn into a fascination with modes of immediate relation to the natural, modes more obviously and externally active than those the fat man endured on the beach (his activity there was of an imagination looking for points of focus). In the Kapowsin poems many of the men doing the relating, when not the fat man himself, are the kinds of companions with whom he feels most at ease. This is to say that he is looking less for variety of experience than for possibilities within a special mode, his own, and on a special locale, the edge of a river. The confrontation has shifted from a beach at the margin of a (usually) unmoving sea to the bank of a river, flowing water which carries fish, flotsam and several possibilities of a kind of relationship which is as rich in its limitations as in its depth. Though there is far more in Death of the Kapowsin Tavern than river poems, it is that group which leads off the book and gives it its ground tone, a tone which never leaves, even in a framework of more civil things to which only limited access is possible. This is a difficult world for steelhead and for people. But, though the world may be nicer to steelhead than it is to people, it is nice to people because there are steelhead in it. Steelhead and jacks make possible a mode of communication that can cause the usually unhearing to respond. We can plunge within their surroundings through an extension of ourselves, enter the depths of the vital center and get a response of shuddering struggle which ends either with flight or limpness, but ends only after the harsh tension of communication has been fought through. When a line shoots over the surface of a winter river there is a gesture of silent speech, a radical vernacular through which contact from one side of the edge is made to the other. Its syntax is the lineaments of snare and struggle. Few of these fishermen stand there burning for the kind of marginal sustenance one has to grub out of indifferent matter. They are there at the edge to make points against strangeness:

These men are never cold. Their faces

burn with winter and their eyes

are hot. They see, across the flat,

the black day coming for them 
and the black sea. Good wind

mixes with the bourbon in their bones.

("Plunking the Skagit")

This is exploratory language, as clean in its way as the diction of Run of Jacks, again with no open spaces and with a sense that no corner of the world or a phrase is without life. It explores with more ease and confidence, though, with a gradual opening up that is to lead eventually (though not fully in this book) to the composed gift of self in the Italian poems and in those that went back to Montana. Hugo sees what he has always seen, but the immense pressure-which was partly due to a need to keep his world closed off and tight-is no longer there at the limit where the words are just kept from flying apart. The fat man is still a tough guy but flaunts it somewhat less, even in "Duwamish Head," his autobiography. Hugo's consciousness is still elemental and conservative, bound deeply into the enduring forms of confrontation. There is no greater acceptance of marginal struggles in Death of the Kapowsin Tavern but there is less imminent hysteria in it about what happens at the edges. Now he wants to work his eyes to their limit, see all the contours of the confrontation, explore what it can mean to men aside from grubbing for rudimentary support from flora. The eye returns from its work, its actions transmuted into a language which is precise and percipient, taut but not strained, ruthless in its quest for exactness of sight and statement:

No lovers love in grass along the shore.

The corn is often stunted. There's some hope in churches, outlined clean on hills behind the town. But what design. In stores, prices climb each payday. The artist ends up weakly painting buckeye cows.

Mexican and Serb-bending backs and sweatEuropean cursing in the grove-wages weak as yesterday's manure: I should see injustice, not slow water and the beating birds that never move a foot against the sun.

("Bad Vision at the Skagit")

The foreign is no friendlier than before, nor do backs break any less easily; but the eye which watches the line streak over and into the river sees itself, its subjects and objects, in more complex relations which do not exclude compassion but now have to include a warming awe. No one loves anything or himself more or less. Brutality (from that which ignores us) still follows meaningless laws. But Hugo has opened himself up, still with the fat man's occasional self-pity and penchant for self-dramatization-now, though, with a vision whose sharpness precludes neither awe nor (and this is new) something like a circumspect regard. One should not exaggerate the extent of this movement or the regard: Hugo loves no antagonists. Yet the relations between men and their opposites on the other side of the edge now have more diversity within them, and that recognition of diver- 
sity has come along with an easing of stance and verbal pressure that makes his style suppler in its assertions about itself and what it molds into being:

Gold. Not gold, but blue. The tan bird

in and out of sunlight hugs the stream.

Now he uses cedar bark for amber,

takes the color of a hostile man.

He has no taste. How satisfied he seems

anywhere he flies throughout the spectrum.

("The Colors of a Bird")

The sweep of truth that pushes through these limber rhythms is deep but restricted. The meeting at the boundary finds profound veracity in the fact of its activity and in the acuity of Hugo's awed vision and language, but the scope of what it can know rarely goes far. Hugo works in a difficult field. He wants to explore the possible relationships but the very business of exploration may well cancel out any chance of understanding: "To know is to be alien to rivers" or so says the fat man in "Duwamish Head;" and as he stands where the road ends at Tahola he has less to ask from the sea and therefore learns more of the meaning of waters:

See the gleam,

the stars that once were fish and died.

We kiss between the fire and the ocean.

In the morning we will start another stare

across the gray. Nowhere mare nostro.

Don't claim it and the sea belongs to you.

("Road Ends at Tahola")

Any truth picked up under these circumstances-and the poems attest to what he has won-comes partly through luck, partly through a cunning that cons out of seas and rivers what they did not know they owned and could give away.

The title of the last section of the book, "Limited Access," carries the scope of this difficult activity into explorations of the relations between men and their own kind, between Hugo himself and those he has known, and between men and the places and art they have made. Men are, in some ways, as difficult to get at as steelhead, but Hugo knows things about the being of roomers in stale flats, a dead drinking companion and a fort that has lost its guns that he cannot even guess at about the inside of the Duwamish. Some scenes in this last section are not unexpected, but the poems of waters have given these poems about men and their places a depth that makes apparent the limited access that exists everywhere that Hugo can reach. Yet there is a kind of enlightenment available here and now on a stream's bank. And there is an even fuller understanding possible about people and their places, an understanding whose motive force is the brooding compassion that had been held back in Run of Jacks but begins now, as a warm and fertile under-layer, to break through the tough guy's defenses. Access is never less than limited, but no lure can get deeper into the center of a stream than Hugo's compassion gets into the world of his pained kind or the beauty of a place's stubborn oldness. He is an authority on a sort of hurt that people under- 
go, and he knows that it is not landscapes but other people who are the enemies of the grubby and the unattractive. The world of men is crammed with their victims, fat Eileens and obstructive squatters. Places can be obstructions too:

Let the columns rot, progressive mayors deny

a city has a private right to be.

Let the market slide into the sea.

The sea has meat, is derelict and kind.

Snapper, red from failure, live on sun.

No bass ever knew another, and the pompano

like men arranged to be alone.

("Pike Place Market")

What is fertile to mind has to be fought over as a living repository, because a dead one has its being richly in the mind, but only there:

Nothing dies as slowly as a scene.

The dusty jukebox cracking through

the cackle of a beered-up crone-

wagered wine-sudden need to dance-

these remain in the black debris.

Although I know in time the lake will send

wind black enough to blow it all away.

("Death of the Kapowsin Tavern")

This sensibility, chilled by black winds and cherishing repositories, defines what Hugo carries with him wherever he moves. But by the point of the last poems in Death of the Kapowsin Tavern the voice of the sensibility had begun to flex and modulate its tone, and was doing so with a new fluency made possible because the voice was turning toward the reader. In the earlier poems of Run of Jacks the voice delineated its world with fantastic exactness but gave little of itself. Many of those poems revealed a gripping of self, a refusal to expose the personality, which echoed here and there in the clenched tensions of the language and occasionally made of those tensions a reflection of the voice's impulse toward a protective hardness. I have already mentioned the easing in the speech of Death of the Kapowsin Tavern. This easing occurred when the voice moved from what could have been shrill (though it rarely was) toward the gradual revelation of a personality which owned more confidence about its private complexities. The poetry as a whole was progressing, always tentatively, toward the fuller rendering of a selfhood which knew itself better with each poem but never stopped seeing and recording what was always apparent to its sensibility.

The poems in Good Luck in Cracked Italian, Hugo's third book, record an interlude in which he explores the relationships between the changing voice of the poems and what endured in the content of their vision. He came to Italy with all the guilt hung over from the period of flinging bombs from five miles up, but, even more, with a curiosity about what he had been then and what he can see now of where he was. The chill winds blow in Italy too, on a ground fertile with incidents of marginal confrontation and the monuments in which repose more memories than even Hugo can imagine himself into. He can see all that 
his sensibility knows best but see it elsewhere than at home, and with a private warmth that expands the scope of both content and response:

This is futile, Sharks don't carry notes.

What's your face like now with slow eels

sliding through your eyes? Bones can't glow

through barnacles and green piled dark as flak.

Your seatbelt rots too late. If wings

could bring you up and tricky currents

float you seas and seas to here, I'm not sure

I'd know you or would like your jokes.

Dick, I went back to those rocks today, and sat there, glaring at the sea.

("Note from Capri to Richard Ryan

on the Adriatic Floor")

But there is nothing in this openness of voice which carries on the confessional mode of the fifties and sixties. Hugo is too much a fan of Valéry to keep the poem anywhere else but between himself and the reader, shaping the sound of the voice so that we can believe in it and accept what it says, but never making of the voice a shriek directly out of his own substance. Only Lowell and Sylvia Plath have managed that fierce drive out of substance with consistent success. Their ways were never within the range of possibilities Hugo could have examined. Yet this openness which tempers his urgencies without denying them is not all or exclusive. Nothing he had learned to say or be is left out of the Italian poems because, though they say little about the Northwest, they include everything he had come to see at all points in time and in the spaces of his world and his personality. There is, then, no essential change in style but an accretion of variety and therefore of flexibility, an enrichment of the potentials of mood. Some of the poems in the Italian book echo the sinewy toughness of an earlier mode of voice but now that the toughness is not all that there is it sometimes finds a kind of pleasure even in its own mature seeing:

Cruelty is what a land endures before

it's clean. Years of torture here

fan out from us, brown miles of monument

and dome, pigeons rising pink in haze

and broken women scattered on the stream.

We stand on stone and holy violence

of men, and even late in afternoon,

Rome seen from a parapet is always dawn.

("Castel Sant'Angelo")

The inner and outer landscapes continue to shift and play against each other but the enrichment of the possibilities of voice is matched by a concomitant complexity in the modulations of the outer landscape. Nothing has changed but much more has emerged as this least Blakean of contemporaries cleanses the doors of his perception and enlarges the range of the window which joins both 
landscapes. Within that range all that is old in Italy gives fully of itself, not because it is mellifluously Italian (the hurt he knows well is here too) but because nothing in any of his worlds is without reference to the human, and the human in the voice is now triumphantly emergent and aware of the fullest meanings. What these poems completed in the movement of self that began with the earliest poems was taken back to the West, to Montana's towns, streams and Indians. It may be that Hugo had to step out of his home for awhile to complete himself. When he returned from the Italian interlude he settled into subsequent poems with a skilled comfort that found no corners closed off to him:

Say no to yourself. The old man, twenty

when the jail was built, still laughs

although his lips collapse. Someday soon,

he says, I'll go to sleep and not wake up.

You tell him no. You're talking to yourself.

The car that brought you here still runs.

The money you buy lunch with, no matter where it's mined, is silver and the girl who serves you food is slender and her red hair lights the wall.

("Degrees of Gray in Philipsburg")

Hugo has spoken of Roethke's influence on him and of his early interest in the poems of Bernard Spencer, who deserves more than the unheard praise of aficionados. But his true relations are with poets like William Stafford, on whom Hugo has written, and with the great Welshman R. S. Thomas. Both Hugo and Thomas -and Stafford, to some extent-are tied deeply into elemental things that never change, and each stares hard at the people who differ little from those elements. These poets, and a few others like them, hold onto the minimally enduring with a fervid conservatism that has nothing to do with politics and everything with people for whom no change seems possible. These cold pastorals come down from Wordsworth, who taught us all to see starkness with a compassion that cannot bubble but opens a place for warmth where there had been only hardness. Hugo fits in this line, whose significance in our time we ought to recognize, though there are not now many poets who work in it. Of those who do he is one of the best. That should suffice for anyone's distinction.

\section{Two Poems by Richard Hugo}

\section{HOT SPRINGS}

You arrived arthritic for the cure, therapeutic qualities of water and the therapeutic air. Twenty-five years later you limp out of bars hoping rumors will revive, some doctor will discover something curative 